\title{
Quantification of Tryptic Peptides in Quadrupole Ion Trap Using High-Mass Signals Derived from Isotope-Coded $N$-Acetyl Dipeptide Tags
}

\author{
Jongcheol Seo, Hye-Joo Yoon, Seung Koo Shin
}

Department of Chemistry, Bio-Nanotechnology Center, Pohang University of Science and Technology, Pohang, Kyungbuk 790-784, Korea

\begin{abstract}
Isotope-labeled $N$-acetyl dipeptides (Ac-Xxx-Ala) are coupled to the primary amines of tryptic peptides and then analyzed by tandem mass spectrometry. Amide bond cleavage between $\mathrm{Xxx}$ and Ala provides both low- and high-mass isotope-coded signals for quantification of peptides. Especially, facile cleavage at the modified lysine side chain yields very strong high-mass quantitation signals in a noise-free region. Tagging tryptic peptides with isobaric $N$-acetyl dipeptides is a viable strategy for accurate quantification of proteins, which can be used with most quadrupole ion trap mass spectrometers carrying the 1/3 mass cut-off problem.
\end{abstract}

Key words: Isobaric tag, Quantitative proteomics, High-mass quantitation signal, Quadrupole ion trap mass spectrometry, $N$-acetyl dipeptide

\section{Introduction}

I sobaric tags have been widely used in the mass spectrometry (MS)-based quantification of proteins and peptides [1-3]. Peptides of interest are differentially labeled with isotopecoded tags and the resulting isotopomeric precursor ions are analyzed by tandem mass spectrometry (MS/MS) to identify the peptide sequence and to simultaneously quantify the amounts of differentially-labeled peptides. All of the isobaric tags available to date are designed to report quantitation signals in the $m / z$ 100-250 region [4-13]. However, this low-mass region is inaccessible by conventional quadrupole ion trap (QIT) because of the $\sim 1 / 3$ mass cut-off problem in ion trapping during resonant excitation of the precursor ion [14]. Moreover, the $m / z 100-250$ region is ion-rich due to other small fragment peaks overlapping in this region [10]. Although a couple of novel ion trapping methods have been recently developed to

Electronic supplementary material The online version of this article (doi:10.1007/s13361-011-0189-6) contains supplementary material, which is available to authorized users.

Correspondence to: Seung K. Shin; e-mail: skshin@postech.ac.kr overcome this low-mass cut-off problem [15-18], they are not directly applicable to most QIT mass spectrometers. Alternatively, it would be convenient to come up with a chemical method that provides quantitation signals in a high-mass, noise-free region. Herein, we present results from $N$-acetyl dipeptides coupled to the primary amines of tryptic peptides, which demonstrates the significance of high-mass quantitation signals for quantification of proteins.

Recently, we have reported mass-balanced H/D-isotope tags (MBITs) based on Ac-Xxx-Ala dipeptides terminated with an amine-reactive O-succinimidyl (OSu) ester at the Cterminus (Scheme 1) [10, 11].

$\mathrm{H} / \mathrm{D}$-isotopes are incorporated into the $\mathrm{CH}_{3} / \mathrm{CD}_{3}$ group either in acetyl or in alanine to report 2-plex quantitation signals separated by $3 \mathrm{Da}$. The variable amino acid $\mathrm{Xxx}$ can be chosen either from a natural amino acid [10] or from an artificial amino acid [11] to diversify MBITs (Xxx-tags). The variation of side chain $\mathrm{R}_{\mathrm{T}}$ shifts quantitation signals and modulates chemical properties of the tagged peptides.

To investigate quantitation signals from MBIT-linked peptides, we prepared two model peptides having the same sequence except for the amino acid at the C-terminus, LISFYAGR (1) and LISFYAGK (2). Their sequences were 


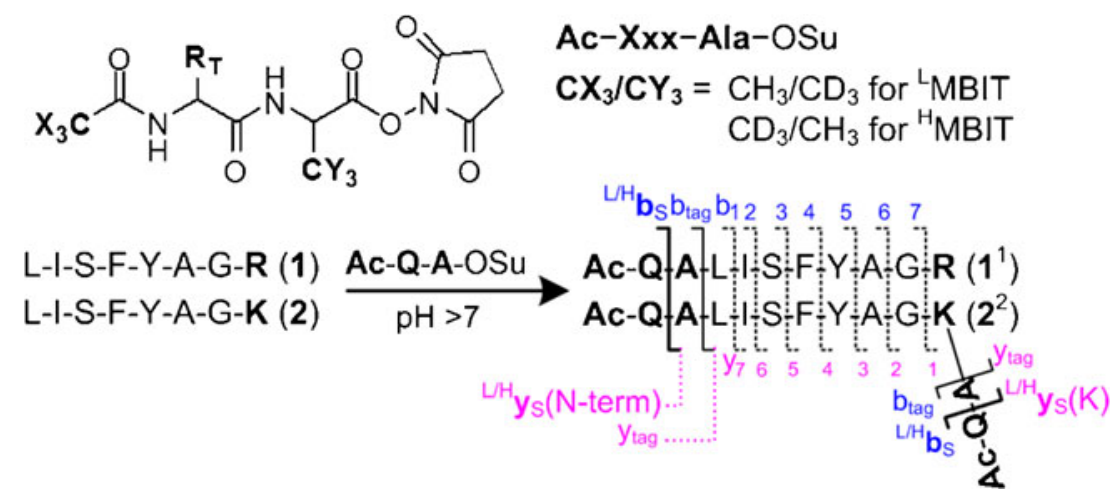

Scheme 1. Coupling of H/D-isotope labeled Ac-Xxx-Ala-OSu (Xxx-Tag) to tryptic peptides

arbitrarily chosen from natural amino acids, excluding histidine, proline, aspartic acid, and glutamic acid to avoid specific fragmentation pathways [19]. Of the various MBITs, the Glntag (Ac-Q-A) was conjugated to the model peptides. Aminereactive coupling produced the arginine-terminated peptide $\mathbf{1}$ with one Gln-tag at the N-terminus $\left(\mathbf{1}^{1}\right)$ and the lysineterminated peptide 2 with two Gln-tags $\left(\mathbf{2}^{2}\right)$, one at the Nterminus and another at lysine (Scheme 1). Superscript denotes the number of tags attached to the peptide. Resulting peptides were analyzed by using matrix-assisted laser desorption ionization (MALDI)-time-of-flight (TOF) and electrospray ionization (ESI)-QIT mass spectrometers. Tandem mass analyses of tagged peptides yield both low-mass $\left({ }^{\mathrm{L} / \mathrm{H}} \mathbf{b}_{\mathrm{S}}\right)$ and high-mass $\left({ }^{\mathrm{L} / \mathrm{H}_{\mathrm{S}}}\right)$ quantitation signals through the Gln-Ala peptide bond cleavage (see reference [20] for the nomenclature of peptide fragmentation). The elution profile of MBIT-linked peptides in liquid chromatography (LC) was examined with MBIT-linked peptides $\mathbf{1}^{1}$ and $\mathbf{2}^{2}$. Meanwhile, the performance of MBITs on quantification of proteins in a QIT mass spectrometer was demonstrated with a protein mixture containing bovine serum albumin (BSA), horse myoglobin, and human ubiquitin.

\section{Experimental}

\section{Materials}

Preparation of the acid form of mass-balanced H/D-isotope tag $\left({ }^{\mathrm{L} / \mathrm{H}} \mathrm{MBIT}\right)$ is described elsewhere [10]. $N$-hydroxysuccinimide (NHS), hydroxylamine hydrochloride, $N, N^{\prime}$-dimethylformamide (DMF, HPLC grade), trifluoroacetic acid (TFA), formic acid, and 4-hydroxy- $\alpha$-cyano-cinnamic acid (HCCA) were purchased from Sigma-Aldrich (St. Louis, MO, USA). $N$-(3-dimethylaminopropyl)- $N$ '-ethylcarbodiimide (EDC) hydrochloride and modified trypsin were obtained from Pierce (Rockford, IL) and Promega (Madison, WI, USA), respectively. Model peptides, LISFYAGR (1), LISFYAGK (2), and AARLISFYAGK (3), were purchased from Peptron, Inc. (Daejeon, Korea). BSA was obtained from Merck (Darmstadt, Germany). Both myoglobin and ubiquitin were purchased from Sigma-Aldrich.

\section{Preparation of Succinimidyl Ester of MBIT (MBIT-OSu)}

${ }^{\mathrm{L} / \mathrm{H}} \mathrm{MBIT}$ was dissolved in DMF to a final concentration of $80 \mathrm{mM}$. A solution containing EDC $(140 \mathrm{mM})$ and NHS $(160 \mathrm{mM})$ was prepared in DMF. The ${ }^{\mathrm{L} / \mathrm{H}} \mathrm{MBIT}-\mathrm{OH}$ solution $(6 \mu \mathrm{L})$ was mixed with the EDC/NHS solution $(2 \mu \mathrm{L})$ in a $0.6 \mathrm{~mL}$ Eppendorf-tube to prepare an O-succinimidyl ester $(\mathrm{OSu})$ form of MBIT. The ${ }^{\mathrm{L} / \mathrm{H}} \mathrm{MBIT}$ reagent was added in excess in order to consume EDC, thereby preventing the formation of active esters of target peptides in the subsequent peptide conjugation. A freshly-prepared ${ }^{\mathrm{L} / \mathrm{H}}$ MBIT$\mathrm{OSu}$ solution $(35 \mathrm{mM})$ was promptly used for peptide conjugation without further purification.

\section{Preparation of MBIT-Linked Peptides $\mathbf{1}^{1}, 2^{2}$, and $3^{2}$}

Each model peptide was dissolved in sodium bicarbonate buffer $(100 \mathrm{mM}, \mathrm{pH} 8.1)$ to a final concentration of $250 \mu \mathrm{M}$. Each peptide solution $(8 \mu \mathrm{L})$ was mixed with the ${ }^{\mathrm{L}} \mathrm{MBIT}-\mathrm{OSu}$ or ${ }^{\mathrm{H}}$ MBIT-OSu solution $(8 \mu \mathrm{L})$ in an Eppendorf-tube. After stirring the mixture at room temperature for $2 \mathrm{~h}$, hydroxylamine $(100 \mathrm{mM}$ in $100 \mathrm{mM}$ sodium bicarbonate buffer, $8 \mu \mathrm{L}$ ) was added to the mixture in order to minimize side reactions on hydroxyl groups and to consume excess ${ }^{\mathrm{L}} \mathrm{MBIT}-\mathrm{OSu}$ or ${ }^{\mathrm{H}}$ MBIT-OSu reagent [10]. The reaction was carried out for more than $6 \mathrm{~h}$ and terminated with 10\% TFA $(4 \mu \mathrm{L})$. The final volume of each sample solution was $28 \mu \mathrm{L}$. As-prepared MBIT-linked peptide solution was purified with ZipTip- $\mu \mathrm{C}_{18}$ column (Millipore, San Diego, CA, USA), and then further diluted to a proper concentration before MS and MS/MS.

\section{Preparation of MBIT-Linked Peptide $2^{l}$}

${ }^{\mathrm{L} / \mathrm{H}}$ MBIT-linked peptide $\mathbf{3}^{2}$ was digested with trypsin to obtain peptide $2^{1}$ conjugated with only one MBIT at lysine. ${ }^{\mathrm{L} / \mathrm{H}} \mathrm{MBIT}$ linked peptide $\mathbf{3}^{2}$ was diluted in aqueous sodium bicarbonate buffer $(80 \mathrm{mM})$ to the final concentration of $50 \mu \mathrm{M}$, and an aliquot $(95 \mu \mathrm{L})$ was mixed with a trypsin solution $\left(0.1 \mu \mathrm{g} \mu \mathrm{L}^{-1}\right.$, $5 \mu \mathrm{L}$ ) and incubated at $37^{\circ} \mathrm{C}$ for $12 \mathrm{~h}$. Trypsin reaction was 
terminated by adding $10 \%$ TFA $(10 \mu \mathrm{L})$. The tryptic digest of peptides was dried under vacuum, reconstituted in distilled water $(10 \mu \mathrm{L})$, purified with ZipTip- $\mu \mathrm{C}_{18}$ column, and then diluted to a proper concentration before MS and MS/MS.

\section{Quantitation Linearity Measurement}

${ }^{\mathrm{L}}$ MBIT- and ${ }^{\mathrm{H}} \mathrm{MBIT}-$ linked peptides were diluted with acetonitrile/water/formic acid $(50 / 50 / 0.5, \mathrm{vol} / \mathrm{vol})$ to a final concentration of $10 \mu \mathrm{M}$ and then mixed together in various volume ratios: ${ }^{\mathrm{L}} \mathrm{MBIT} /{ }^{\mathrm{H}} \mathrm{MBIT}=1,4,9,16,25,36,49$, and 64. The volume of each mixture was $300 \mu \mathrm{L}$ and the lowest concentration of ${ }^{\mathrm{H}}$ MBIT-linked peptide was approximately $154 \mathrm{nM}$. This premixed sample was analyzed by ESI-MS and MS/MS. Each MS/MS spectrum was acquired for $15 \mathrm{~s}$.

\section{MALDI and ESI Mass Analyses of Model Peptides}

For MALDI, MBIT-linked peptides $(1 \mu \mathrm{M})$ were mixed with HCCA $\left(5 \mu \mathrm{g} \mu \mathrm{L}^{-1}\right)$ in acetonitrile/water/TFA (50/50/0.1, vol/ $\mathrm{vol})$, and then the mixture $(0.5 \mu \mathrm{L})$ was loaded on a MALDI plate. MALDI-MS and MS/MS were performed using a 4700 Proteomics Analyzer (TOF/TOF; AB SCIEX, Foster City, CA, USA). Air $\left(1.5 \times 10^{-7}\right.$ torr $)$ was used as collision gas for TOF/ TOF. For ESI, MBIT-linked peptides $(5 \mu \mathrm{M})$ were dissolved in acetonitrile/water/formic acid (50/50/0.5, vol/vol). ESI-MS and MS/MS were performed using a high-capacity ion trap (HCT, Bruker Daltonics, Germany). The sample solution was loaded on a syringe pump, and then sprayed through an electrospray emitter at the flow rate of $\sim 1 \mu \mathrm{L} \mathrm{min}{ }^{-1}$. Electrospray voltage was $3.5 \mathrm{kV}$ under $\mathrm{N}_{2}$ nebulizer gas (5 psi). Helium $\left(\sim 1.5 \times 10^{-5}\right.$ torr) was used as collision gas for QIT-MS/MS.

\section{LC Elution Profiles of MBIT-Linked Peptides}

LC elution profiles were obtained through multiplereaction monitoring (MRM) mode using a 2000 Q-TRAP triple-quadrupole mass spectrometer (AB SCIEX, Forster City, CA, USA) connected to reverse-phase nano-LC system (LC Packings, Sunnyvale, CA, USA). ${ }^{\mathrm{L}}$ MBITand ${ }^{\mathrm{H}}$ MBIT-linked peptides $\mathbf{1}^{1}$ and $\mathbf{2}^{2}$ were mixed together in a 1:1 ratio and diluted to the final concentration of $20 \mu \mathrm{M}$ with a $0.1 \%$ TFA solution. The mixture was analyzed by nano-LC-ESI-MRM. The precursor ion was selected in Q1 and fragmented in Q2. Of the fragment ions, quantitation signal ions (either ${ }^{\mathrm{L} / \mathrm{H}} \mathbf{b}_{\mathrm{S}}$ or $\mathrm{H} / \mathbf{L}_{\mathrm{S}}$ ) were selected in $\mathrm{Q} 3$ at unit resolution and their abundances were recorded every $0.8 \mathrm{~s}$. LC running conditions are described in the Supplementary Material.

\section{Quantification of Proteins}

Three proteins (BSA, horse myoglobin, and human ubiquitin) were mixed in two different ratios (sample $\mathrm{A}$ and $\mathrm{B}$ ). Sample A contains $4.0 \mathrm{mg} \mathrm{mL}^{-1}$ of BSA, $2.0 \mathrm{mg} \mathrm{mL}^{-1}$ of myoglobin, and $0.2 \mathrm{mg} \mathrm{mL} \mathrm{m}^{-1}$ of ubiquitin in aqueous sodium bicarbonate buffer $(80 \mathrm{mM})$, whereas sample B contains $2.0 \mathrm{mg} \mathrm{mL}^{-1}$ of BSA, $0.5 \mathrm{mg} \mathrm{mL}^{-1}$ of myoglobin, and $0.4 \mathrm{mg} \mathrm{mL}^{-1}$ of ubiquitin. Each protein mixture $(80 \mu \mathrm{L})$ was digested with trypsin $\left(0.1 \mu \mathrm{g} \mu \mathrm{L}^{-1}\right.$ of trypsin, $\left.20 \mu \mathrm{L}\right)$ for $18 \mathrm{~h}$ at $38{ }^{\circ} \mathrm{C}$. Tryptic peptides of sample A and B $(20 \mu \mathrm{L}$ each) were mixed with ${ }^{\mathrm{L}}$ MBIT-OSu and ${ }^{\mathrm{H}}$ MBIT-OSu (20 $\mu \mathrm{L}$ each), respectively. Each MBIT-peptide mixture was stirred at room temperature for $2 \mathrm{~h}$, and then treated with hydroxylamine $(100 \mathrm{mM}$ in $100 \mathrm{mM}$ sodium bicarbonate buffer, $20 \mu \mathrm{L}$ ) for $6 \mathrm{~h}$. The conjugation reaction was terminated with $10 \%$ TFA $(10 \mu \mathrm{L})$. The MBIT-linked sample $\mathrm{A}$ and $\mathrm{B}(10 \mu \mathrm{L}$ each $)$ were mixed together, dried under vacuum, and reconstituted in $0.5 \%$ formic acid $(10 \mu \mathrm{L})$. An aliquot of the mixture $(5 \mu \mathrm{L})$ was analyzed by nano-LC-ESIMS and MS/MS using an LTQ XL linear ion trap mass spectrometer (Thermo Scientific, Waltham, MA, USA) connected to a nano-LC system (Eksigent, Dublin, CA, USA). LC running conditions are described in the Supplementary Material. Peptide sequencing and protein identification was carried out by Mascot MS/MS ion search with a custom-built protein database containing 26,269 bovine, horse, and human proteins. Of the MS/MS peak lists, the precursor ions that yielded a tagging-signature ion $\mathrm{y}_{\mathrm{tag}}{ }^{n+}$ indicating the loss of neutral Ac-Q-A $(-244.1 / n)$ were fed into the Mascot search. The $m / z$ tolerance was $0.5 \mathrm{Da}$, and the MBIT tagging was considered as a variable modification at the $\mathrm{N}$-terminus and lysine.

\section{Results and Discussion}

\section{MALDI-TOF Mass Analyses of MBIT-Linked Peptides $\mathbf{1}^{1}$ and $\mathbf{2}^{2}$}

The MALDI-TOF mass spectra of the 1:1 mixture of ${ }^{\mathrm{L}}$ MBIT- and ${ }^{\mathrm{H}}$ MBIT-linked peptides, Ac-QA-LISFYAGR $\left(\mathbf{1}^{1}\right)$, and Ac-QA-LISFYAGK-AQ-Ac $\left(\mathbf{2}^{2}\right)$, display a strong protonated ion peak $\left[1^{1}+\mathrm{H}\right]^{+}$at $\mathrm{m} / z 1170.6$ and a weak sodiated ion peak $\left[\mathbf{2}^{2}+\mathrm{Na}\right]^{+}$at $m / z 1408.9$ (Figure 1a). This result indicates that coupling reactions between the Gln-tag (Ac-Q-A) and model peptides $\mathbf{1}$ and $\mathbf{2}$ proceed to completion. However, no protonated peptide $\mathbf{2}^{2}$ is detected because both the $\varepsilon$-amine of lysine and the $\mathrm{N}$-terminal amine are modified to the less basic amides. Thus, only the arginineterminated peptide ion $\left[\mathbf{1}^{1}+\mathrm{H}\right]^{+}$was further characterized. The TOF-MS/MS analysis of $\left[\mathbf{1}^{1}+\mathrm{H}\right]^{+}$shows low-mass ${ }^{\mathrm{L} / \mathrm{H}} \mathbf{b}_{\mathrm{S}}$ ions at $m / z$ 171.1/174.1 in addition to b- and y-type sequence ions, but no complementary ${ }^{\mathrm{H} / \mathrm{L}} \mathbf{y}_{\mathrm{S}}$ ions at $\mathrm{m} / \mathrm{z}$ 1000.6/997.6 (Figure 1b). The relative abundance of a pair of ${ }^{\mathrm{L} / \mathrm{H}} \mathbf{b}_{\mathrm{S}}$ ions is about $20 \%$ of the total fragment ions.

\section{ESI-QIT Mass Analyses of $\mathbf{1}^{1}$ and $\mathbf{2}^{2}$}

The ESI-QIT mass spectra of the $1: 1{ }^{\mathrm{L}} \mathrm{MBIT} /{ }^{\mathrm{H}}$ MBIT-linked peptide mixture show strong singly and doubly protonated ion peaks, $\left[\mathbf{1}^{1}+\mathrm{H}\right]^{+}$at $m / z 1170.6,\left[\mathbf{1}^{1}+2 \mathrm{H}\right]^{2+}$ at $\mathrm{m} / \mathrm{z} 585.8$, $\left[\mathbf{2}^{2}+\mathrm{H}\right]^{+}$at $m / z \quad 1387.0$, and $\left[\mathbf{2}^{2}+2 \mathrm{H}\right]^{2+}$ at $\mathrm{m} / \mathrm{z}$ 694.0. In 

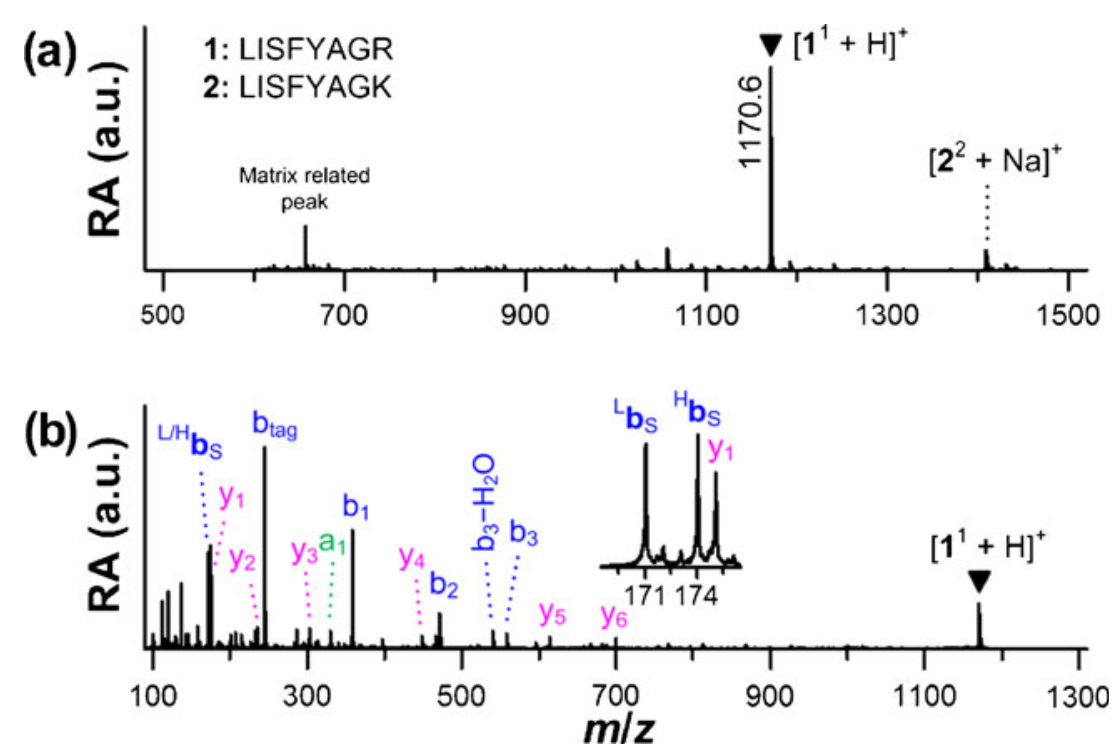

Figure 1. (a) MALDI-TOF mass spectra of the $1: 1$ mixture of ${ }^{\mathrm{L} M B I T-}$ and ${ }^{\mathrm{H}} \mathrm{MBIT}$-linked peptides, LISFYAGR (1) and LISFYAGK (2). MBIT refers to a Gln-tag (Ac-Q-A). (b) TOF-MS/MS spectra of $\left[1^{1}+\mathrm{H}\right]^{+}$. Of the fragments, a (green), b (blue), and y (magenta) ions are marked. Low-mass ${ }^{L / H} \mathbf{b}_{S}$ ions are expanded in the inset. $R A=$ relative abundance

addition, $\left[\mathbf{2}^{2}+\mathrm{Na}\right]^{+}$and $\left[\mathbf{2}^{2}+\mathrm{K}\right]^{+}$ion peaks are also detected (Figure 2a). All four protonated peptide ions were further characterized.

Collisional activation of $\left[\mathbf{1}^{1}+\mathrm{H}\right]^{+}$in QIT yields singly protonated ${ }^{\mathrm{L} / \mathrm{H}} \mathbf{y}_{\mathrm{S}}$ ions at $\mathrm{m} / \mathrm{z}$ 997.6/1000.6 with a number of sequence ions, but no peaks in the low-mass cut-off range (Figure 2b). The relative abundance of ${ }^{\mathrm{L} / \mathrm{H}} \mathbf{y}_{\mathrm{S}}$ is only $1.8 \%$ of the total fragment ions. $\left[\mathbf{1}^{1}+\mathrm{H}\right]^{+}$mainly undergoes a loss of ammonia from the protonated arginine [21] or a loss of water from the serine or tyrosine side chain $[22,23]$. The tandem mass analysis of $\left[\mathbf{1}^{1}+2 \mathrm{H}\right]^{2+}$ also provides singly protonated ${ }^{\mathrm{L} / \mathrm{H}} \mathbf{y}_{\mathrm{S}}$ ions, but no peaks below the low-mass cut-off (Figure 2c).

In contrast to $\left[1^{1}+\mathrm{H}\right]^{+}$, a series of $\mathrm{b}$ - and $\mathrm{y}$-type sequence ions are abundantly produced from $\left[\mathbf{1}^{1}+2 \mathrm{H}\right]^{2+}$, suggesting that although one proton is fixed at arginine, another proton is mobile to facilitate the peptide backbone fragmentation $[24,25]$. Nevertheless, the relative abundance of singly protonated ${ }^{\mathrm{L} / \mathrm{H}} \mathbf{y}_{\mathrm{S}}$ is only $2.2 \%$ of the total fragment ions. The measured $\left[{ }^{\mathrm{H}} \mathbf{y}_{\mathrm{S}}\right] /\left[\mathbf{y}_{\mathrm{S}}^{\mathrm{L}}\right]$ ratios from $\left[\mathbf{1}^{1}+\mathrm{H}\right]^{+}$and $\left[\mathbf{1}^{1}+2 \mathrm{H}\right]^{2+}$ are 0.87 and 0.55 , respectively, both of which deviate significantly from the premixed ${ }^{\mathrm{L}} \mathrm{MBIT} /{ }^{\mathrm{H}} \mathrm{MBIT}$ ratio of 1.0 . The singly protonated ${ }^{\mathrm{L}} \mathbf{y}_{\mathrm{S}}$ ion from both $\left[\mathbf{1}^{1}+\mathrm{H}\right]^{+}$and $\left[\mathbf{1}^{1}+\right.$ $2 \mathrm{H}]^{2+}$ overlaps with the isotope pattern of the $b_{7}$ ion that results from a loss of the C-terminal arginine (174.1 Da) (inset of Figure $2 b$ and $c$ ). By subtracting the $b_{7}$ isotope, we can obtain the correct $\left[{ }^{\mathrm{H}} \mathbf{y}_{\mathrm{S}}\right] /\left[{ }^{\mathrm{L}} \mathbf{y}_{\mathrm{S}}\right]$ ratio of 1.05 and 1.02 from $\left[\mathbf{1}^{1}+\mathrm{H}\right]^{+}$and $\left[\mathbf{1}^{1}+2 \mathrm{H}\right]^{2+}$, respectively. In the case of Gln-tag, the $b_{\tilde{n} 1}$ ions of arginine-terminated peptides can always interfere with singly protonated ${ }^{\mathrm{L}} \mathbf{y}_{\mathrm{S}}$ ions. Although one can avoid this accidental overlap by using other MBITs such as His- and Phe-tags, potential overlap between quantitation signals and other ions needs to be examined carefully when various MBITs are employed to quantify complex peptide mixtures.

By contrast, the QIT-MS/MS spectra of $\left[2^{2}+\mathrm{H}\right]^{+}$and $\left[\mathbf{2}^{2}+\right.$ $2 \mathrm{H}]^{2+}$ report strong ${ }^{\mathrm{L} / \mathrm{H}} \mathbf{y}_{\mathrm{S}}$ ions at $\mathrm{m} / \mathrm{z} 1213.7 / 1216.7$ with the 1:1 intensity ratio (Figure $2 \mathrm{~d}$ and e). ${ }^{\mathrm{L} / \mathrm{H}} \mathbf{b}_{\mathrm{S}}$ ions at $\mathrm{m} / z$ 171.1/ 174.1 are not detected due to the low-mass cut-off. In the case of $\left[2^{2}+\mathrm{H}\right]^{+}$, both water- and tag-loss ion peaks are abundant, whereas sequence ions are not. For $\left[2^{2}+2 \mathrm{H}\right]^{2+}$, sequence ions are quite abundant. The relative abundance of a pair of ${ }^{\mathrm{L} / \mathrm{H}} \mathbf{y}_{\mathrm{S}}$ ions from $\left[2^{2}+\mathrm{H}\right]^{+}$is $48 \%$ and that from $\left[2^{2}+2 \mathrm{H}\right]^{2+}$ is $18 \%$. Relative abundances of sequence ions, water-loss and tag-loss ion peaks from $\left[2^{2}+\mathrm{H}\right]^{+}$are $11 \%, 21 \%$, and $20 \%$, respectively, whereas those from $\left[2^{2}+2 \mathrm{H}\right]^{2+}$ are $65 \%, 5 \%$, and $12 \%$, respectively. Most importantly, high-mass ${ }^{\mathrm{L} / \mathrm{H}} \mathbf{y}_{\mathrm{S}}$ ions appear in a noise-free region without any overlap with sequence ions as all of the $b_{1}-b_{7}$ and $y_{1}-y_{7}$ sequence ions fall between $b_{\text {tag }}$ and $\mathrm{y}_{\text {tag }}$ ions. These singly protonated ${ }^{\mathrm{L} / \mathrm{H}_{\mathrm{S}}} \mathbf{y}_{\mathrm{S}}$ ions are derived from a loss of Ac-Q from $\left[\mathbf{2}^{2}+\mathrm{H}\right]^{+}$and a loss of $[\mathrm{Ac}-\mathrm{Q}+\mathrm{H}]^{+}$ from $\left[2^{2}+2 \mathrm{H}\right]^{2+}$. Meanwhile, doubly protonated ${ }^{\mathrm{L} / \mathrm{H}_{\mathrm{S}}} \mathbf{y}_{\mathrm{S}}{ }^{2+}$ ions at $\mathrm{m} / \mathrm{z}$ 607.3/608.8 result from a loss of neutral Ac-Q from $\left[2^{2}+2 \mathrm{H}\right]^{2}$. These ${ }^{\mathrm{L} / \mathrm{H}} \mathbf{y}_{\mathrm{S}}{ }^{2+}$ ions can also be used as quantitation signals.

Evidently, reporting both $\mathbf{b}_{\mathrm{S}}$ and complementary $\mathbf{y}_{\mathrm{S}}$ signal ions is a unique feature of $\mathrm{N}$-acetyl dipeptide tags $[10,11]$. To the contrary, other isobaric tags based on piperazine $[4,5,8,9]$, piperidine $[6,7]$, or tertiary amine $[12,13]$ derivatives report strong low-mass quantitation signals, but no complementary high-mass signals.

\section{ESI-QIT MS $S^{3}$ Analyses of $2^{2}$ and $M S^{2}$ Analyses of $2^{1}$}

There are two Gln-tags linked in $\mathbf{2}^{2}$, one at the N-terminus and another at the lysine side chain, and one of which can 

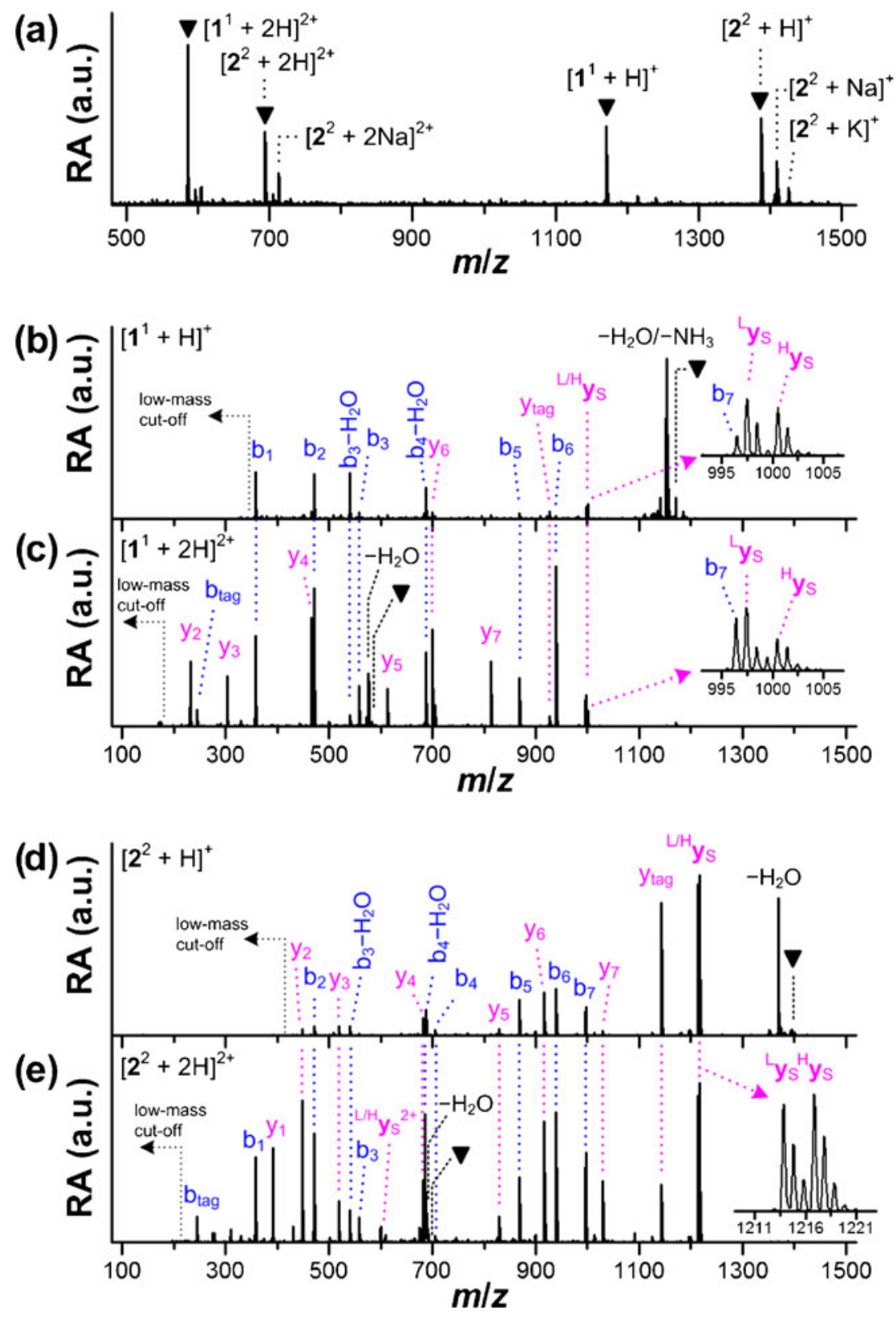

Figure 2. (a) ESI-QIT mass spectra of the 1:1 mixture of ${ }^{\mathrm{L}} \mathrm{MBIT}$ - and ${ }^{\mathrm{H}} \mathrm{MBIT}$-linked peptides $\mathbf{1}^{1}$ and $\mathbf{2}^{2}$. MBIT refers to a GIn-tag (Ac-Q-A). QIT-MS/MS spectra of (b) $\left[1^{1}+\mathrm{H}\right]^{+}$, (c) $\left[1^{1}+2 \mathrm{H}\right]^{2+}$, (d) $\left[2^{2}+\mathrm{H}\right]^{+}$, and (e) $\left[2^{2}+2 \mathrm{H}\right]^{2+}$. Of the fragments, b (blue) and y (magenta) ions are marked. High-mass ${ }^{\mathrm{L} / \mathrm{H}} \mathbf{y}_{\mathrm{S}}$ ions are expanded in the inset (b, $\mathrm{c}$, and e). Loss of water or ammonia is denoted by $-\mathrm{H}_{2} \mathrm{O}$ or $-\mathrm{NH}_{3}$. $\mathrm{RA}=$ relative abundance

lose Ac-Q through the Gln-Ala bond cleavage to yield singly protonated ${ }^{\mathrm{L} / \mathrm{H}} \mathbf{y}_{\mathrm{S}}$ ions. To establish their origin, we isolated the ${ }^{\mathrm{H}} \mathbf{y}_{\mathrm{S}}$ ion at $\mathrm{m} / \mathrm{z} 1216.7$ and carried out collisioninduced dissociation $\left(\mathrm{MS}^{3}\right)$. The ${ }^{\mathrm{L} / \mathrm{H}} \mathbf{y}_{\mathrm{S}}$ ions originated from the N-terminus are denoted by ${ }^{\mathrm{L} / \mathrm{H}} \mathbf{y}_{\mathrm{S}}(\mathrm{N}$-term), whereas those from the lysine side chain is denoted by ${ }^{\mathrm{L} / \mathrm{H}} \mathbf{y}_{\mathrm{S}}(\mathrm{K})$. The $\mathbf{y}_{\mathrm{S}}(\mathrm{N}-$ term) ion would yield both $b_{n}{ }^{\prime}$ ions containing Ala at the Nterminus and $\mathrm{y}_{\mathrm{n}}$ ions containing an intact Gln-tag at the Cterminal lysine, whereas the $\mathbf{y}_{\mathrm{S}}(\mathrm{K})$ ion would yield both $\mathrm{b}_{\mathrm{n}}$ ions containing an intact Gln-tag at the N-terminus and $\mathrm{y}_{\mathrm{n}}{ }^{\prime}$ ions containing $\mathrm{Ala}$ at the $\mathrm{C}$-terminal lysine. The $\mathrm{MS}^{3}$ spectra of ${ }^{\mathrm{H}} \mathbf{y}_{\mathrm{S}}$ derived from both $\left[2^{2}+\mathrm{H}\right]^{+}$and $\left[2^{2}+2 \mathrm{H}\right]^{2+}$ show almost identical fragmentation patterns containing a series of $b_{n}$ and $y_{n}{ }^{\prime}$ ions (Figure $3 a$ and $b$ ). Thus, loss of Ac$\mathrm{Q}$ mainly results from the Gln-tag appended to the $\varepsilon$-amine of lysine $(\mathrm{K})$. The fragmentation patterns also suggest that sequence information can be obtained from $\mathrm{MS}^{3}$ of ${ }^{\mathrm{L} / \mathrm{H}} \mathbf{y}_{\mathrm{S}}(\mathrm{K})$ because the intact Gln-tag attached to the N-terminus shifts all of the b-type sequence ions to a region above the lowmass cut-off.

To substantiate the major formation of ${ }^{\mathrm{L} / \mathrm{H}} \mathbf{y}_{\mathrm{S}}(\mathrm{K})$ ions through the Gln-Ala cleavage at the lysine side chain, we prepared peptide $2^{1}$ having only one Gln tag at lysine. For this, another model peptide AARLISFYAGK (3) was 

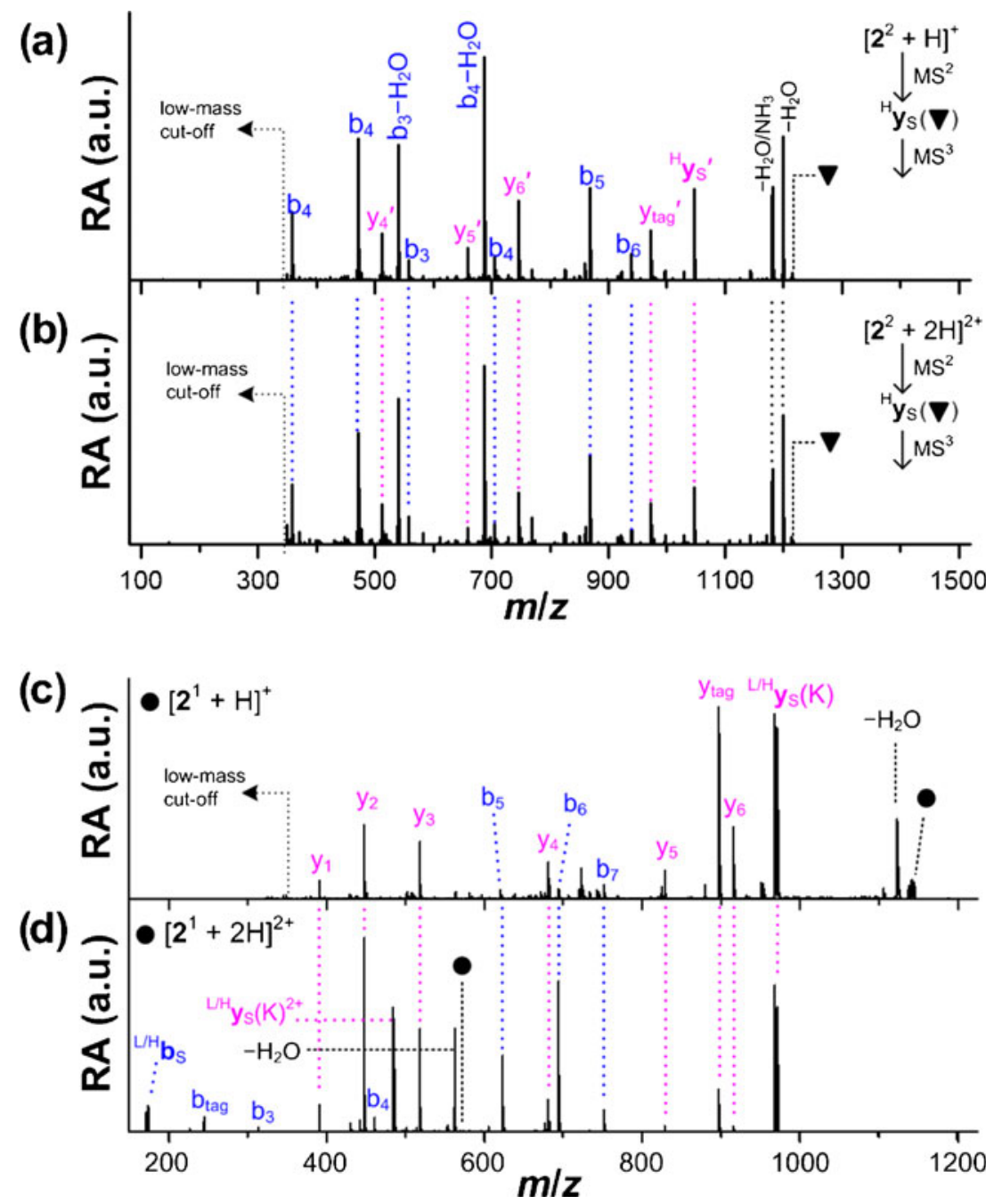

Figure 3. QIT-MS ${ }^{3}$ spectra of the ${ }^{\mathrm{H}} \mathbf{y}_{\mathrm{S}}$ ion at $\mathrm{m} / \mathrm{z} 1216.7$ derived from (a) $\left[\mathbf{2}^{2}+\mathrm{H}\right]^{+}$and (b) $\left[\mathbf{2}^{2}+2 \mathrm{H}\right]^{2+}$ and QIT-MS ${ }^{2}$ spectra of the 1:1 mixture of ${ }^{\mathrm{L}} \mathrm{MBIT}$ - and ${ }^{\mathrm{H}} \mathrm{MBIT}$-linked peptides $2^{1}$, (c) $\left[\mathbf{2}^{1}+\mathrm{H}\right]^{+}$and $(\mathrm{d})\left[\mathbf{2}^{1}+2 \mathrm{H}\right]^{2+}$. Of the fragments, b (blue) and y (magenta) ions are marked. Primed ions contain Ala at the C-terminal lysine $\left(\mathrm{y}_{\mathrm{n}}{ }^{\prime}\right)$. Loss of water and loss of water plus ammonia are denoted by $-\mathrm{H}_{2} \mathrm{O}$ and $-\mathrm{H}_{2} \mathrm{O} / \mathrm{NH}_{3}$, respectively. $\mathrm{RA}=$ relative abundance

conjugated with two Gln-tags, one at the N-terminus and another at the lysine side chain, and then digested with trypsin to cleave off Ac-QAAAR. The QIT-MS/MS spectra of $\left[2^{1}+\mathrm{H}\right]^{+}$and $\left[2^{1}+2 \mathrm{H}\right]^{2+}$ from the 1:1 mixture of ${ }^{\mathrm{L}} \mathrm{MBIT}-$ and ${ }^{\mathrm{H}}$ MBIT-linked peptide $\mathbf{2}^{1}$ show strong ${ }^{\mathrm{H} / \mathrm{L}} \mathbf{y}_{\mathrm{S}}(\mathrm{K})$ ion peaks in the high-mass region (Figure $3 \mathrm{c}$ and $\mathrm{d}$ ), which are almost identical to the fragmentation patterns of $\left[2^{2}+\mathrm{H}\right]^{+}$ and $\left[2^{2}+2 \mathrm{H}\right]^{2+}$ (Figure $2 \mathrm{~d}$ and e), respectively. In the case of $\left[2^{1}+2 \mathrm{H}\right]^{2+}$, the complementary low-mass ${ }^{\mathrm{H} / \mathrm{L}} \mathbf{b}_{\mathrm{S}}$ ions are also detected above the low-mass cut-off. Apparently, $N$-acetyl dipeptide appended to the lysine side chain is a primary source of strong ${ }^{\mathrm{L} / \mathrm{H}} \mathbf{y}_{\mathrm{S}}$ signals from both $\mathbf{2}^{2}$ and $\mathbf{2}^{1}$.

\section{Quantitation Linearity Using High-Mass ${ }^{H / L} \boldsymbol{y}_{S}$ Signals from Lysine-Tagged Peptides}

The quantitation linearity of ${ }^{\mathrm{H} / \mathrm{L}} \mathbf{y}_{\mathrm{S}}$ signals was checked by mixing ${ }^{\mathrm{L}}$ MBIT- and ${ }^{\mathrm{H}}$ MBIT-linked peptide $\mathbf{2}^{2}$ in various ratios. A linear relationship was found between measured and premixed $\left[{ }^{\mathrm{H}} \mathbf{y}_{\mathrm{S}}\right] /\left[{ }^{\mathrm{L}} \mathbf{y}_{\mathrm{S}}\right]$ ratios up to the mixed ratio of $36: 1$

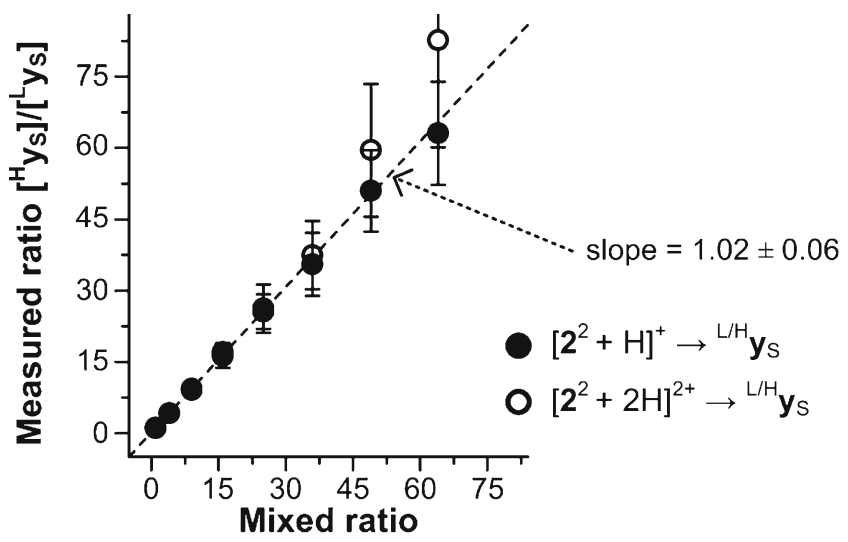

Figure 4. Relationship between measured $\left[{ }^{H} y_{S}\right] /\left[y_{S}\right]$ ratios and mixed peptide ratios. Error bar denotes the standard deviation from six measurements 
with $[2+2 \mathrm{H}]^{2+}$ and of $64: 1$ with $[2+\mathrm{H}]^{+}$(Figure 4). In comparison, other isobaric tags reporting low-mass quantitation signals show a linearity up to the mixed ratio of about $16: 1$ to $25: 1$ [26].

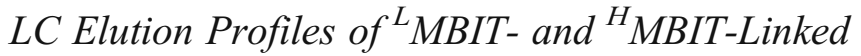 Peptides}

We have previously shown that ${ }^{\mathrm{L} / \mathrm{H}} \mathrm{MBIT}$-linked peptides are co-eluted in LC by taking the MALDI-TOF/TOF [10] or ESI-MS/MS spectra [11]. In the present study, we examined LC elution profiles of the 1:1 mixture of the ${ }^{\mathrm{L}} \mathrm{MBIT}-$ and ${ }^{\mathrm{H}}$ MBIT-linked peptides $\mathbf{1}^{1}$ and $\mathbf{2}^{2}$ by obtaining the ESI-MS/ MS spectra, as described in the Experimental section. In the case of $\left[\mathbf{1}^{1}+\mathrm{H}\right]^{+}$, we monitored ${ }^{\mathrm{L} / \mathrm{H}} \mathbf{b}_{\mathrm{S}}$ ions in MRM mode using a triple quadrupole mass spectrometer because the relative abundance of ${ }^{\mathrm{L} / \mathrm{H}} \mathbf{b}_{\mathrm{S}}$ ions from $\left[\mathbf{1}^{1}+\mathrm{H}\right]^{+}$was $20 \%$ in the MALDI-TOF/TOF spectra, whereas that of ${ }^{\mathrm{H} / \mathrm{L}} \mathbf{y}_{\mathrm{S}}$ ions was only $1.8 \%$ in the ESI-QIT-MS/MS spectra. For $\left[2^{2}+\mathrm{H}\right]^{+}$, we recorded ${ }^{\mathrm{H} / \mathrm{L}} \mathbf{y}_{\mathrm{S}}$ ions in MRM mode because their relative abundance was $48 \%$ in the ESI-QIT-MS/MS spectra. The extracted ion chromatograms (XICs) of unmodified peptides 1 and 2 were obtained separately by taking the ESI-MS spectra. XICs are depicted in Figure 5; (a) unmodified peptides $[\mathbf{1}+\mathrm{H}]^{+}$ and $[2+\mathrm{H}]^{+} ;$(b) ${ }^{\mathrm{L} / \mathrm{H}} \mathbf{b}_{\mathrm{S}}$ from $\left[\mathbf{1}^{1}+\mathrm{H}\right]^{+} ;$(c) ${ }^{\mathrm{H} / \mathrm{L}} \mathbf{y}_{\mathrm{S}}$ from $\left[\mathbf{2}^{2}+\mathrm{H}\right]^{+}$. Unmodified peptides $\mathbf{1}$ and $\mathbf{2}$ are eluted at 7.06 and $6.93 \mathrm{~min}$, respectively (Figure 5a), whereas MBIT-linked peptides $\mathbf{1}^{1}$ and $2^{2}$ are eluted at 13.94 and $16.73 \mathrm{~min}$, respectively (Figure 5b and c). MBIT conjugation increases the mass as well as the number of hydrophobic amino acids and, thus, retards the elution time by $6.88 \mathrm{~min}$ for $\mathbf{1}^{1}$ and by $9.80 \mathrm{~min}$ for $\mathbf{2}^{2}$ relative to $\mathbf{1}$ and $\mathbf{2}$, respectively. Nevertheless, both ${ }^{\mathrm{L}} \mathrm{MBIT}$ - and ${ }^{\mathrm{H}}$ MBIT-linked peptides $\mathbf{1}^{1}$ are co-eluted at the same time with the $\left[{ }^{\mathrm{L}} \mathbf{b}_{\mathrm{S}}\right] /\left[{ }^{\mathrm{H}} \mathbf{b}_{\mathrm{S}}\right]$ ratio of $1.02 \pm 0.07$ (Figure $5 \mathrm{~b}$ ), and both ${ }^{\mathrm{L}}$ MBIT- and ${ }^{\mathrm{H}}$ MBIT-linked peptides $2^{2}$ are also co-eluted at the same time with the $\left[{ }^{\mathrm{H}} \mathbf{y}_{\mathrm{S}}\right] /\left[{ }^{\mathrm{L}} \mathbf{y}_{\mathrm{S}}\right]$ ratio of $0.99 \pm 0.05$
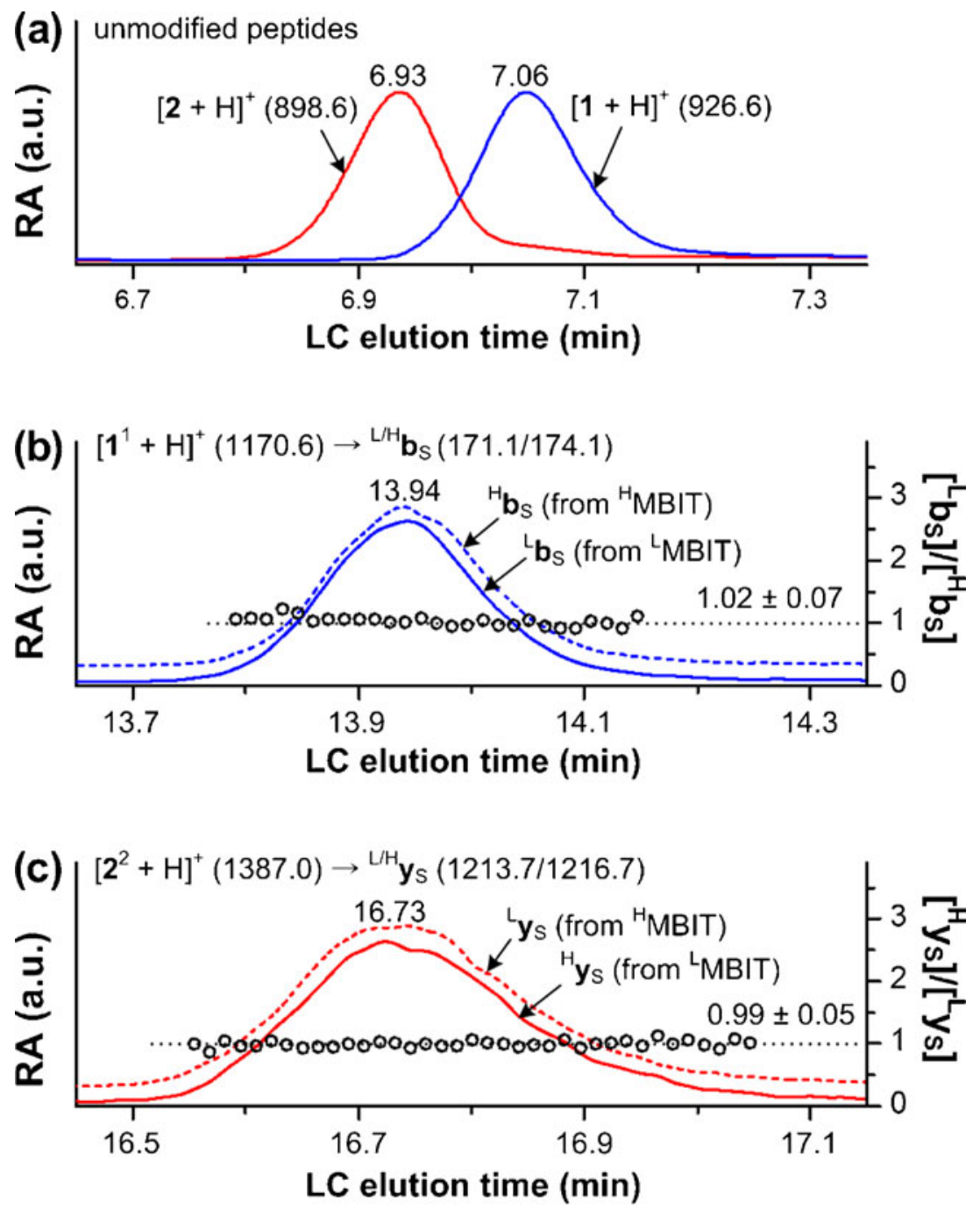

Figure 5. Extracted ion chromatograms of (a) unmodified peptides $\mathbf{1}$ and $\mathbf{2}$ obtained from the ESI-MS spectra using a triple quadrupole mass spectrometer, (b) ${ }^{\mathrm{L} / \mathrm{H}} \mathrm{MBIT}$-linked peptide $1^{1}$ obtained from the ESI-MS/MS spectra monitoring ${ }^{\mathrm{L} / \mathrm{H}_{\mathrm{S}}}$ ions, and (c) ${ }^{\mathrm{L} / \mathrm{H}}$ MBIT-linked peptide $\mathbf{2}^{2}$ obtained from the ESI-MS/MS spectra monitoring ${ }^{\mathrm{H} / \mathrm{L}} \mathbf{y}_{\mathrm{S}}$ ions. RA=relative abundance 

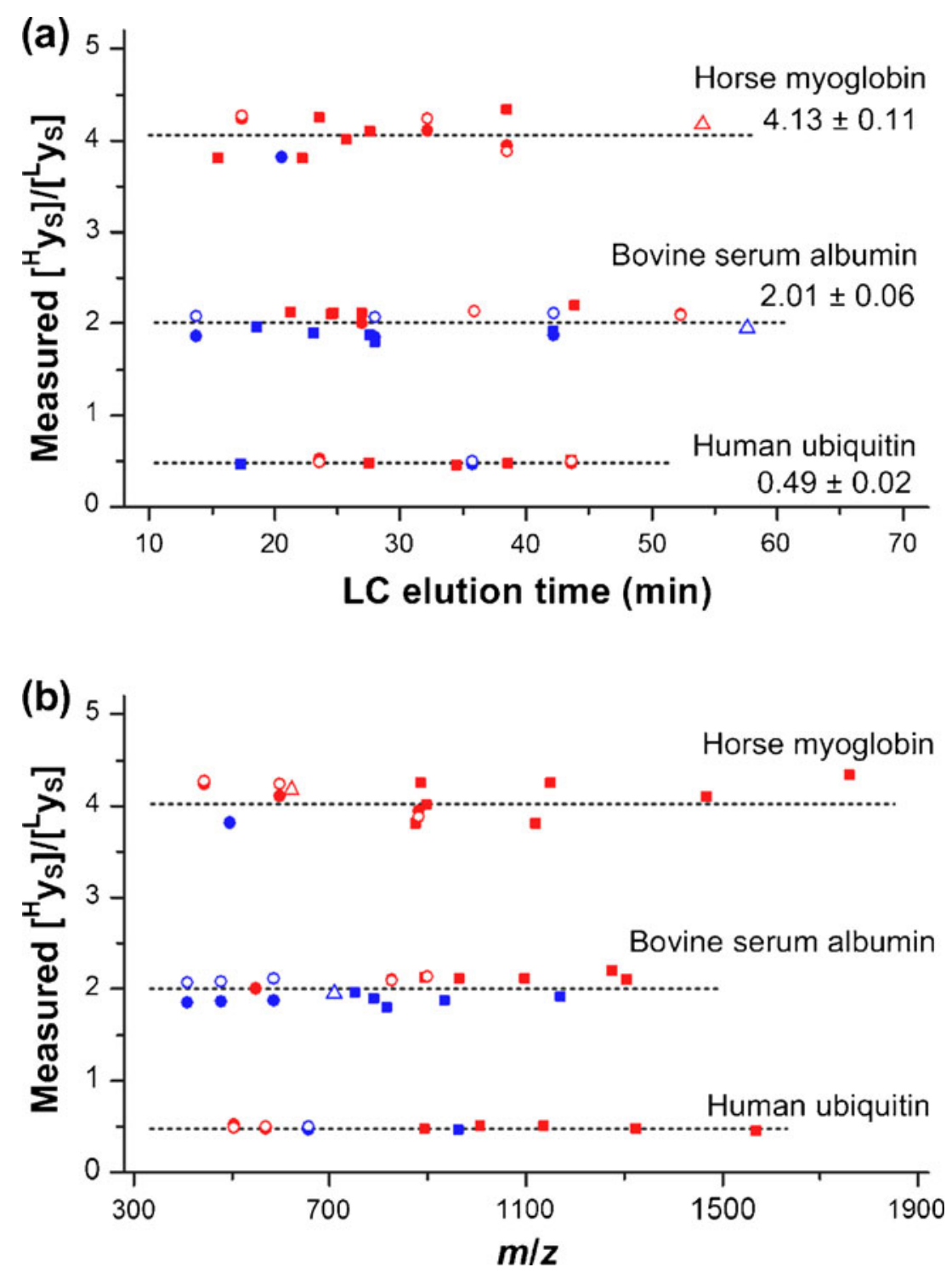

Figure 6. $\left[{ }^{\mathrm{H}} \mathbf{y}_{\mathrm{S}}\right] /\left[{ }^{\mathrm{L}} \mathbf{y}_{\mathrm{S}}\right]$ ratios obtained from LC-ESI-QIT-MS/MS analyses as a function of (a) LC elution time and (b) $\mathrm{m} / z$ of MBITlinked peptides. The three charge states of MBIT-linked peptides are denoted by square for $1+$, circle for $2+$, and triangle for $3+$. Lysine- and arginine-terminated peptides are marked in red and blue, respectively. Solid and open symbols refer to the [ $\left.{ }^{\mathrm{H}} \mathbf{y}_{\mathrm{S}}\right] /$ $\left[{ }^{L} \mathbf{y}_{S}\right.$ ] ratios obtained from singly and doubly protonated ${ }^{\mathrm{H} / L} \mathbf{y}_{S}$ ions, respectively. Average values of $\left[{ }^{\mathrm{H}} \mathbf{y}_{S}\right] /\left[{ }^{\mathrm{L}} \mathbf{y}_{S}\right]$ and ${ }^{95 \%}$ confidence intervals are given

(Figure 5c). Although it is well known that $\mathrm{H}-$ and $\mathrm{D}-$ labeled peptides can be resolved in LC [27], the coelution of ${ }^{\mathrm{L} / \mathrm{H}}$ MBIT-linked isotopomeric peptides suggests that $\mathrm{H} / \mathrm{D}$-isotope effects on the $\mathrm{LC}$ retention time are cancelled out by isobaric $\mathrm{H} / \mathrm{D}$-labeling on $N$-acetyl dipeptide.

\section{Quantification of a Protein Mixture}

The relative amounts of proteins in a sample mixture are quantified by obtaining the $\left[{ }^{\mathrm{H}} \mathbf{y}_{\mathrm{S}}\right] /\left[{ }^{\mathrm{L}} \mathbf{y}_{\mathrm{S}}\right]$ ratio, which represents the ratio of ${ }^{\mathrm{L}}$ MBIT-linked peptides from sample A to ${ }^{\mathrm{H}}$ MBIT-linked peptides from sample B. The premixed ratios of [protein in sample A]/[protein in sample B] are 2.0 for BSA, 4.0 for myoglobin, and 0.5 for ubiquitin. The Mascot
MS/MS ion search identified BSA (MOWSE score of 439) from fifteen MBIT-linked peptides (16\% amino acid coverage), myoglobin (score of 364) from 10 (43\% coverage), and ubiquitin (score of 244$)$ from seven ( $46 \%$ coverage). These amino acid coverages were comparable to those obtained from the MALDI-TOF analysis of a protein mixture (unlabeled) in a methanol-water digest solution (17\% for BSA, $40 \%$ for myoglobin, and $85 \%$ for ubiquitin) [28]. Identified peptides are listed in Tables S1, S2, S3 and S4 in the Supplementary Material. Of the 32 MBIT-linked tryptic peptides, 28 were fully modified, whereas four were partly modified at the lysine side chain only. The relative abundance of each partly modified peptide was only 5\%$9 \%$ of the fully modified peptide with the same sequence. 
Thus, MBIT labeling reactions were proceeded to near completion. Notably, all MBIT-linked lysine-terminated peptides are found in the $1+$ and $2+$ charge states, whereas arginine-terminated peptides are found in $1+, 2+$, and $3+$ charge states. The $\left[{ }^{\mathrm{H}} \mathbf{y}_{\mathrm{S}}\right] /\left[{ }^{\mathrm{L}} \mathbf{y}_{\mathrm{S}}\right]$ ratios are plotted as a function of LC elution time and $\mathrm{m} / \mathrm{z}$ in Figure 6a and b, respectively. MBIT-linked peptides are eluted in LC between 10 and $60 \mathrm{~min}$ (Figure 6a) and distributed in the $\mathrm{m} / \mathrm{z}$ range from 400 to 1900 (Figure 6b). The $\mathbf{y}_{\mathrm{S}}$ ions derived from lysine- and arginine-terminated peptides are marked in red and blue, respectively. Although singly protonated peptides yield only singly protonated ${ }^{\mathrm{H} / \mathrm{L}} \mathbf{y}_{\mathrm{S}}$ ions, doubly protonated peptides result in both singly and doubly protonated ${ }^{\mathrm{H} / \mathrm{L}} \mathbf{y}_{\mathrm{S}}$ ions, whereas triply protonated peptides produce both doubly and triply protonated ${ }^{\mathrm{H} / \mathrm{L}} \mathbf{y}_{\mathrm{S}}$ ions. Of the three types of ${ }^{\mathrm{H} / \mathrm{L}} \mathbf{y}_{\mathrm{S}}$ ions, singly and doubly protonated ${ }^{\mathrm{H} / \mathrm{L}} \mathbf{y}_{\mathrm{S}}$ ions (denoted by solid and open symbols, respectively) are used for quantification. The measured [protein $]_{\mathrm{A}} /[\text { protein }]_{\mathrm{B}}$ ratios determined from $\left[{ }^{\mathrm{H}} \mathbf{y}_{\mathrm{S}}\right] /\left[{ }^{\mathrm{L}} \mathbf{y}_{\mathrm{S}}\right]$ values are $2.01 \pm 0.06$ for BSA, $4.13 \pm 0.11$ for myoglobin, and $0.49 \pm 0.02$ for ubiquitin, which is in excellent agreement with the premixed ratios within $5 \%$ error. Both lysine- and arginine-terminated MBIT-linked peptides provide accurate results for protein quantification.

\section{Conclusions}

We present a strategy for accurate quantification of peptides and proteins in quadrupole ion trap using highmass isotope-coded signals derived from $N$-acetyl dipeptide tags. Differentially labeled MBIT-linked tryptic peptides are co-eluted in LC with little H/D isotope effects. Isobaric MBIT-linked peptides result in low-mass b-type signal ions in the MALDI-TOF/TOF spectra and high-mass y-type signal ions in the ESI-QIT-MS/MS spectra, which is complementary to each other. Of the MBIT-linked tryptic peptides, singly protonated lysineterminated peptides yield strong high-mass quantitation signal ions whose relative abundances are nearly $50 \%$ of the total fragment ions. $\mathrm{N}$-acetyl dipeptide tags allow accurate identification and quantification of tryptic peptides, regardless of the type of mass spectrometers.

\section{Acknowledgments}

The authors are grateful for the support from the Functional Proteomics Center (grant FPR08A1-040). They also thank to the Ulsan National Institute of Science and Technology Central Research Facility (UCRF), the Peptide Library Support Facility (PLSF) at the POSTECH Biotechnology Center, and D. H. Hwang for technical assistance.

\section{References}

1. Rix, U., Superti-Furga, G.: Target Profiling of Small Molecules by Chemical Proteomics. Nat. Chem. Biol. 5, 616-624 (2009)

2. Bantscheff, M., Schirle, M., Sweetman, G., Rick, J., Kuster, B.: Quantitative Mass Spectrometry in Proteomics: A Critical Review. Anal. Bioanal. Chem. 389, 1017-1031 (2007)
3. Iliuk, A., Galan, W., Tao, A.: Playing Tag with Quantitative Proteomics. Anal. Bioanal. Chem. 393, 503-513 (2009)

4. Ross, P.L., Huang, Y.N., Marchese, J.N., Williamson, B., Parker, K., Hattan, S., Khainovski, N., Pillai, S., Daniels, S., Purkayastha, S., Juhasz, P., Martin, S., Barlet-Jones, M., He, F., Jacobson, A., Pappin, D.: Multiplexed Protein Quantitation in Saccharomyces cerevisiae Using Amine-Reactive Isobaric Tagging Reagents. Mol. Cell. Proteomics 3, 1154-1169 (2004)

5. Choe, L., D'Ascenzo, M., Relkin, N.R., Pappin, D., Ross, P., Williamson, B., Guertin, S., Pribil, P., Lee, K.H.: 8-Plex Quantitation of Changes in Cerebrospinal Fluid Protein Expression in Subjects Undergoing Intravenous Immunoglobulin Treatment for Alzheimer's Disease. Proteomics 7, 3651-3660 (2007)

6. Dayon, L., Hainard, A., Licker, V., Turck, N., Kuhn, K., Hochstrasser, D.F., Burkhard, P.R., Sanchez, J.-C.: Relative Quantification of Proteins in Human Cerebrospinal Fluids by MS/MS Using 6-Plex Isobaric Tags. Anal. Chem. 80, 2921-2931 (2008)

7. Dayon, L., Turck, N., Kienle, S., Schulz-Kanppe, P., Hochstrasser, D. F., Scherl, A., Sanchez, J.-C.: Isobaric Tagging-Based Selection and Quantitation of Cerebrospinal Fluid Tryptic Peptides with Reporter Calibration Curves. Anal. Chem. 82, 848-858 (2010)

8. Li, S., Zeng, D.: CILAT-A New Reagent for Quantitative Proteomics. Chem. Commun. 2181-2183 (2007)

9. Zeng, D., Li, S.: Improved CILAT Reagents for Quantitative Proteomics. Bioorg. Med. Chem. Lett. 19, 2059-2061 (2009)

10. Seo, J., Suh, M.-S., Thangadurai, T.D., Kim, J., Rhee, Y.H., Yoon, H.J., Shin, S.K.: Mass-Balanced ${ }^{1} \mathrm{H} /{ }^{2} \mathrm{H}$ Isotope Dipeptide Tag for Simultaneous Protein Quantitation and Identification. Anal. Chem. 80, 6145-6153 (2008)

11. Suh, M.-S., Seo, J., Thangadurai, T.D., Rhee, Y.H., Shin, S.K., Yoon, H.-J.: Aliphatic Dipeptide Tags for Multi 2-Plex Protein Quantification. Analyst 136, 1614-1619 (2011)

12. Zeng, D., Li, S.: Revival of Deuterium-Labeled Reagents for Protein Quantitation. Chem. Commun. 3369-3371 (2009)

13. Zhang, J., Wang, Y., Li, S.: Deuterium Isobaric Amine-Reactive Tags for Quantitative Proteomics. Anal. Chem. 82, 7588-7595 (2010)

14. Payne, A.H., Glish, G.L.: Thermally Assisted Infrared Multiphoton Photodissociation in a Quadrupole Ion Trap. Anal. Chem. 73, 35423548 (2001)

15. Cunningham, C., Glish, G.L., Burinsky, D.J.: High Amplitude Short Time Excitation: A Method to Form and Detect Low Mass Product Ions in a Quadrupole Ion Trap Mass Spectrometer. J. Am. Soc. Mass Spectrom. 17, 81-84 (2006)

16. Griffin, T.J., Xie, H., Bandhakavi, S., Popko, J., Mohan, A., Carlis, J. V., Higgins, L.: iTRAQ Reagent-Based Quantitative Proteomic Analysis on a Linear Ion Trap Mass Spectrometer. J. Proteome Res. 6, 4200-4209 (2007)

17. Boja, E.S., Phillips, D., French, S.A., Harris, R.A., Balaban, R.S.: Quantitative Mitochondrial Phosphoproteomics Using iTRAQ on an LTQ-Orbitrap with High Energy Collision Dissociation. J. Proteome Res. 8, 4665-4675 (2009)

18. Köcher, T., Pichler, P., Schutzbier, M., Stingl, C., Kaul, A., Teucher, N., Hasenfuss, G., Penninger, J.M., Mechtler, K.: High Precision Quantitative Proteomics Using iTRAQ on an LTQ Orbitrap: A New Mass Spectrometric Method Combining the Benefits of All. $J$ Proteome Res. 8, 4743-4752 (2009)

19. Paizs, B., Suhai, S.: Fragmentation Pathways of Protonated Peptides. Mass Spectrom. Rev. 24, 508-548 (2005)

20. Roepstorff, P., Fohlmann, J.: Proposal for a Common Nomenclature for Sequence Ions in Mass Spectra of Peptides. Biomed. Mass Spectrom. 11, $601(1984)$

21. Csonka, I.P., Paizs, B., Suhai, S.: Modeling of the Gas-Phase Ion Chemistry of Protonated Arginine. J. Mass Spectrom. 39, 1025-1035 (2004)

22. Ballard, K.D., Gaskell, S.J.: Dehydration of Peptide $[\mathrm{M}+\mathrm{H}]^{+}$Ions in the Gas Phase. J. Am. Soc. Mass Spectrom. 4, 477-481 (1993)

23. Reid, G.E., Simpson, R.J., O'Hair, R.A.J.: Leaving Group and GasPhase Neighboring Group Effects in the Side Chain Losses from Protonated Serine and Its Derivatives. J. Am. Soc. Mass Spectrom. 11, 1047-1060 (2000)

24. Dongré, A.R., Jones, I.L., Somogyi, Á., Wysocki, V.H.: Influence of Peptide Composition, Gas-Phase Basicity, and Chemical Modification 
on Fragmentation Efficiency: Evidence for the Mobile Proton Model. $J$. Am. Chem. Soc. 118, 8365-8374 (1996)

25. Tsaprailis, G., Nair, H., Somogyi, Á., Wysocki, V.H., Zhong, W., Futrell, J.H., Summerfield, S.G., Gaskell, S.J.: Influence of Secondary Structure on the Fragmentation of Protonated Peptides. J. Am. Chem. Soc. 121, 5142-5154 (1999)

26. Casado-Vela, J., Martínez-Esteso, M.K., Rodriguez, E., Borrás, E., Elortza, F., Bru-Martínez, R.: iTRAQ-Based Quantitative Analysis of
Pprotein Mixtures with Large Fold Change and Dynamic Range. Proteomics 10, 343-347 (2010)

27. Zhang, R., Sioma, C.S., Thompson, R.A., Xiong, L., Regnier, F.E.: Controlling Deuterium Isotope Effects in Comparative Proteomics. Anal. Chem. 74, 3662-3669 (2002)

28. Russell, W.K., Park, Z.Y., Russell, D.H.: Proteolysis in Mixed Organic -Aqueous Solvent Systems: Applications for Peptide Mass Mapping Using Mass Spectrometry. Anal. Chem. 73, 2682-2685 (2001) 